\title{
Development of a Species-Specific SCAR-PCR Assay for Direct Detection of Sugar Beet Cyst Nematode (Heterodera schachtii) from Infected Roots and Soil Samples
}

\author{
Chen Jiang ${ }^{1,+}$, Yingdong Zhang ${ }^{1,+}$, Ke Yao ${ }^{1,2}$, Sulaiman Abdulsalam ${ }^{1}{ }^{1}$, Guangkuo ${ }^{3}{ }^{3}$, Haifeng Gao ${ }^{3}$, \\ Kemei Li ${ }^{4}$, Wenkun Huang ${ }^{1}$, Lingan Kong ${ }^{1}$, Deliang Peng ${ }^{1, * \mathbb{D}}$ and Huan Peng ${ }^{1,3, *(D)}$ \\ 1 State Key Laboratory for Biology of Plant Diseases and Insect Pests, Institute of Plant Protection, \\ Chinese Academy of Agricultural Sciences, Beijing 100193, China; 18684759602@163.com (C.J.); \\ zhangyingdong26@163.com (Y.Z.); 17794539779@163.com (K.Y.); asulaiman@abu.edu.ng (S.A.); \\ wkhuang2002@163.com (W.H.); konglingan@caas.cn (L.K.) \\ 2 College of Agriculture and Biotechnology, Zhejiang University, Hangzhou 310058, China \\ 3 Key Laboratory of Integrated Pest Management on Crop in Northwestern Oasis, Ministry of Agriculture, \\ Institute of Plant Protection, Xinjiang Academy of Agricultural Sciences, Urumqi 830091, China; \\ lgk0808@163.com (G.L.); ghf20044666@163.com (H.G.) \\ 4 College of Agriculture, Xinjiang Agricultural University, Urumqi 830091, China; likemei@xjau.edu.cn \\ * Correspondence: pengdeliang@caas.cn (D.P.); penghuan@caas.cn (H.P.); Tel.: +86-010-62815611 (D.P. \& H.P.) \\ + Equal contribution (co-first authors).
}

Citation: Jiang, C.; Zhang, Y.; Yao, K.; Abdulsalam, S.; Li, G.; Gao, H.; Li, K.; Huang, W.; Kong, L.; Peng, D.; et al. Development of a Species-Specific SCAR-PCR Assay for Direct Detection of Sugar Beet Cyst Nematode (Heterodera schachtii) from Infected Roots and Soil Samples. Life 2021, 11, 1358. https://doi.org/ $10.3390 /$ life11121358

Academic Editors: Yanfeng Hu, Fengjuan Pan and Jingsheng Chen

Received: 1 November 2021

Accepted: 6 December 2021

Published: 7 December 2021

Publisher's Note: MDPI stays neutral with regard to jurisdictional claims in published maps and institutional affiliations.

Copyright: (c) 2021 by the authors. Licensee MDPI, Basel, Switzerland. This article is an open access article distributed under the terms and conditions of the Creative Commons Attribution (CC BY) license (https:/ creativecommons.org/licenses/by/ $4.0 /)$.

\begin{abstract}
Sugar beet cyst nematode (SBCN, Heterodera schachtii) is an important nematode that causes significant yield losses of $25-50 \%$ or more in most areas of sugar beet production worldwide. Rapid and accurate identification of this species is essential to support decisions on pest management. However, the difference between $H$. schachtii and other Heterodera spp. based on morphology is a challenging task. In the present study, a SCAR-PCR assay was developed to identify and differentiate $H$. schachtii in infected root and soil samples. H. schachtii-species-specific SCAR-PCR primers OPA06$\mathrm{HsF}$ and OPA06-HsR were designed from the randomly amplified polymorphic DNA (RAPD) marker amplified with random primer OPA06. The developed primers specifically amplify a 922-bp fragment from the target populations but did not amplify DNA from non-target cyst nematodes including Heterodera, Globodera, Cactodera, and other related species tested in this study. The sensitivity detection indicated that $5 \times 10^{-4}$ of a single cyst, 1/320 of a single second-stage juvenile (J2), or 10 pg of genomic DNA could be detected. The assay accurately identifies the different stages of $H$. schachtii in sugar beet and oilseed rape roots as well as a single J2 in $10 \mathrm{~g}$ of soil. Finally, the SCAR-PCR assay detected $H$. schachtii in seven samples out of the fifteen field samples. The assay will not only be useful for differentiating $H$. schachtii from mixed populations of Heterodera spp. but also for effective detection of the species directly from infested samples. The assay also requires no expertise in the taxonomy and morphology of the species but serves to improve the diagnosis of $H$. schachtii in infested fields.
\end{abstract}

Keywords: sugar beet cyst nematode; Heterodera schachtii; RAPD marker; SCAR-PCR

\section{Introduction}

Sugar beet cyst nematode (SBCN, Heterodera schachtii, Schmidt, 1871) is an economically important plant-parasitic nematode that limits the production of sugar beet across the world [1,2]. It was first identified in Germany in 1859 by Schachti as a plant pathogen when it caused yield reduction in sugar beet cultivation. Today SBCN is distributed in more than 50 countries and was recognized and listed as a quarantine pest by more than 20 countries of the world, including China, to restrict its spread $[3,4]$. The nematode has a wide host range, infecting over 218 plant species belonging to 95 genera and 23 different 
plant families [5,6]. It was also reported to cause yield losses of $25-50 \%$ or more in sugar beet and other crops grown [7].

SBCN belongs to the $H$. schachtii sensu stricto group, which also includes $H$. glycines, $H$. betae, H. ciceri, H. daverti, H. medicaginis, and H. trifolii [8]. Morphological differences between $H$. schachtii and its closely related species can be highly challenging. For example, $H$. trifolii exhibit similar body characteristics and damage symptoms with $H$. schachtii particularly at the field level. However, there are some small morphological and morphometric differences that are useful to differentiate these species in this group at the laboratory level [7]. Therefore, the species identification process is time consuming, laborious, and requires a high level of expertise. In the last few decades, a series of DNA-based molecular detection assays have been reported for the identification and discrimination of Heterodera species, including SBCN. Genetic diversity of SBCN populations was carried out using Random Amplified Polymorphic DNA (RAPD) and Amplified Fragment Length Polymorphism (AFLP) techniques $[9,10]$, Polymerase chain reaction internal-transcribed spacer-restriction fragment length polymorphism (PCR-ITS-RFLP) using MvaI restriction enzyme to distinguish $H$. schachtii from other cyst nematodes [11], and PCR by a speciesspecific primer (SHF6) in combination with the universal primer (rDNA2) that amplifies a DNA fragment of $255 \mathrm{bp}$ [12], and this developed primer (SHF6) was modified and used for qPCR-based detection of H. schachtii with SYBR Green dye [13]. However, Toumi et al. [14] reported that the primer (SHF6) was unable to detect some H. schachtii populations, as this polymorphism is not present in all H. schachtii populations. Gamel et al. [15], also succeeded in developing a multiplex species-specific qPCR assay based on microsatellite loci that simultaneously detect and identify H. schachtii, Globodera pallida, and G. rostochiensis in a mixed population; the limit of detection was five juveniles for $H$. schachtii. As we all know, real-time PCR is an advancement over conventional PCR; however, this assay is still not suitable for poorly equipped laboratories.

The ITS region has been widely used in the design of species-specific PCR primers and has been proven useful in the development of diagnostic tests for the detection of these nematode species $[12,16,17]$. RAPD fingerprints as earlier stated provide a good tool for studying genetic variation at the species level [18-20]. The method has been employed to distinguish between $H$. cruciferae and $H$. schachtii [9]. RAPD yielded reliable and repeatable patterns that separate species or populations of SBCN when the PCR conditions were kept constant. By comparing these patterns, unique fragments can be identified and used to design species-specific primers. The primers can be used to generate the sequence characterized amplified regions (SCAR) for SBCN detection. SCAR assays have also been applied for the detection of many important cyst nematodes, such as G. rostochiensis and G. pallida [21], H. glycines [22,23], and H. filipjevi [24]. However, the use of SCAR-PCR assay has not yet been reported for BSCN detection.

SBCN is considered one of the most important quarantine nematodes in China as well as in the world. The nematode was first reported in Guangdong Province of China in the 1990s [25]; however, this record has yet to be substantiated. Recently, this species has been reported in Xinyuan county, Xinjiang Uygur autonomous region of China based on the morphological and molecular characterization [26]. It is difficult to detect, particularly in early infected host roots; therefore, there is an urgent need to develop a rapid and accurate diagnostic approach for direct detection of the nematode in both plant root and soil samples. This study aimed to develop a sensitive and specific SCAR-PCR assay based on RAPD fragments for the direct detection of $H$. schachtii from infected plant root and soil samples.

\section{Materials and Methods}

\subsection{Nematode Populations}

Nine populations of $H$. schachtii from four countries, 12 other cyst-forming nematode species, and five other related nematode species were used in this study (Table 1). The species identities were based on morphology and verified by ribosomal DNA sequencing 
on the ITS region. The second-stage juveniles (J2s) of $H$. schachtii were hatched in a $3 \mathrm{mM}$ $\mathrm{ZnCl}_{2}$ solution at $25^{\circ} \mathrm{C}$.

Table 1. Plant nematode populations used.

\begin{tabular}{|c|c|c|c|c|}
\hline Species & Species Code & Population Origin & Host & References \\
\hline \multirow{9}{*}{ Heterodera schachtii } & Hs1 & Germany & \multirow{9}{*}{ Sugar beet } & [27] \\
\hline & Hs2 & Xinyuan county Xinjiang, China & & \multirow{4}{*}{ This study } \\
\hline & Hs3 & Xinyuan county Xinjiang, China & & \\
\hline & Hs4 & Xinyuan county Xinjiang, China & & \\
\hline & Hs5 & Xinyuan county Xinjiang, China & & \\
\hline & Hs6 & Belgium $^{a}$ & & [13] \\
\hline & Hs7 & Bozova, Anliurfa Province, Turkey & & \multirow{3}{*}{ [28] } \\
\hline & Hs8 & Karakprü, Anliurfa Province, Turkey & & \\
\hline & Hs9 & Siverek, Anliurfa Province, Turkey & & \\
\hline \multirow{3}{*}{ H. glycines } & $\mathrm{Hg} 01$ & Langfang, Hebei, China & Soybean & \multirow{3}{*}{ [23] } \\
\hline & $\mathrm{Hg} 02$ & Heilongjiang, China & Soybean & \\
\hline & $\mathrm{Hg} 03$ & Henan, China & Soybean & \\
\hline H. sojae & Hso & Jiangxi China & Soybean & [29] \\
\hline H. cruciferae & $\mathrm{Hc}$ & Hubei, China & Oilseed rape & This study \\
\hline H. avenae & Ha & Baxing, Beijing, China & Wheat & {$[30]$} \\
\hline H. filipjevi & Hf & Xuchang, Henan, China & Wheat & {$[31]$} \\
\hline H. latipons & $\mathrm{Hl}$ & Belgium $^{a}$ & Wheat & [32] \\
\hline H. elachista & $\mathrm{He}$ & Hunan, China & Rice & [33] \\
\hline H. amaranthusiae n. sp & Ham & Xuanwei, Yunnan, China & Amaranthus retroflexus & [34] \\
\hline H. zeae & $\mathrm{Hz}$ & Henan, China & Maize & [35] \\
\hline Globodera rostochiensis & $\mathrm{Gr}$ & Belgium $^{a}$ & Potato & \multirow{2}{*}{ [36] } \\
\hline G. pallida & $\mathrm{Gp}$ & Belgium ${ }^{a}$ & Potato & \\
\hline Cactodera cacti & Cc & Liaoning, China & Weeds & [37] \\
\hline Meloidogyne enterolobii & $\mathrm{Me}$ & Wenchang, Hainan, China & Tomato & [38] \\
\hline M. graminicola & $\mathrm{Mg}$ & TikeGyi, Yangon, Myanmar & Rice & [39] \\
\hline M. incognita & $\mathrm{Mi}$ & Langfang Hebei, China & Tomato & [38] \\
\hline M. hapla & Mh & Beijing, China & Rose & [38] \\
\hline Ditylenchus Destructor & $\mathrm{Dd}$ & Hebei, China & Sweet potato & {$[40]$} \\
\hline
\end{tabular}

a These populations were provided by Prof. Maurice Mones (Institute for Agriculture and Fisheries Research (ILVO), Belgium).

\subsection{DNA Extraction}

A single cyst, female or J2, was hand-picked into 0.2-mL PCR tubes containing a total of $20 \mu \mathrm{L}$ lysis buffer (including $7 \mu \mathrm{L} 10 \times$ PCR buffer $(100 \mathrm{mM}$ Tris- $\mathrm{HCl}(\mathrm{pH} 8.9), 500 \mathrm{mM}$ $\mathrm{KCl}$, and $15 \mathrm{mM} \mathrm{MgCl}$ ) (Takara-Bio, Shiga, Japan), $3 \mu \mathrm{L}$ Proteinase $\mathrm{K}(600 \mu \mathrm{g} / \mathrm{mL})$, and $10 \mu \mathrm{L}$ distilled water) separately; crude DNA extract was performed from a single nematode as described by Ou et al. [23]. The pure genome DNA of H. schachtii was isolated from the mass of J2s by the phenol-chloroform method, and the pure genome DNA was quantified using the NanoDrop ND-2000 Spectrophotometer (Thermo Scientific, USA). The genomic DNA of nematode in $0.1 \mathrm{~g}$ of plant root was isolated using Universal Genomic DNA Extraction Kit (Takara-Bio, Shiga, Japan), and the Power Soil ${ }^{\circledR}$ DNA Isolation Kit (MoBio Laboratories Inc. Qiagen, Germantown, MD, USA) was used to isolate DNA from 
soil samples according to the manufacturer's instructions. The genome DNA was stored at $-20^{\circ} \mathrm{C}$.

\subsection{RAPD-PCR-Analysis}

Fifteen different random primers (Table 2) for SBCN assays were selected based on previous reports $[9,23,41]$. The PCR amplification reaction contained $5 \mu \mathrm{L} 10 \times$ PCR buffer, $4 \mu \mathrm{L} 2.5 \mathrm{mM}$ dNTPs, $1 \mathrm{U}$ ExTaq DNA polymerase (Takara-Bio, Shiga, Japan), $3 \mu \mathrm{L} 10 \mu \mathrm{M}$ each primer, $1 \mu \mathrm{L}$ template DNA, and double-distilled water $\left(\mathrm{ddH}_{2} \mathrm{O}\right)$ to a total volume of $50 \mu \mathrm{L}$. The PCR was performed in an $\mathrm{S} 1000^{\mathrm{TM}}$ thermal cycler (Bio-Rad Laboratory, Inc. Hercules, CA, USA) under the following conditions: $5 \mathrm{~min}$ at $95^{\circ} \mathrm{C}, 10$ cycles of $30 \mathrm{~s}$ at $95^{\circ} \mathrm{C}, 40 \mathrm{~s}$ at $45^{\circ} \mathrm{C}, 1 \mathrm{~min}$ at $72{ }^{\circ} \mathrm{C}$, and 20 cycles of $30 \mathrm{~s}$ at $95^{\circ} \mathrm{C}, 40 \mathrm{~s}$ at $55^{\circ} \mathrm{C}, 1 \mathrm{~min}$ at $72{ }^{\circ} \mathrm{C}$, followed by $10 \mathrm{~min}$ at $72{ }^{\circ} \mathrm{C}$, and stored at $4{ }^{\circ} \mathrm{C}$. $\mathrm{ddH}_{2} \mathrm{O}$ was used as a negative control to avoid misinterpretations of the RAPD patterns that may be caused by manual manipulation. A total of $10 \mu \mathrm{L}$ of the PCR products were separated on a $2 \%$ agarose gel, visualized by Gelred gel staining (GelStain, TransGen Biotech Beijing, China), and photographed under UV light. All reactions were repeated twice to confirm the results of the reaction with our target bands.

Table 2. Codes and sequences of primers used in this study.

\begin{tabular}{|c|c|c|c|c|}
\hline Primer Name & Sequence $5^{\prime}-3^{\prime}$ & Types & Production Sizes & References \\
\hline OPA-01 & $5^{\prime}$-CAGGCCCTTC-3' & \multirow{15}{*}{ RAPD primers } & \multirow{15}{*}{ Random, uncertain } & \multirow{15}{*}[9,23,41]{} \\
\hline OPA-02 & 5'-TGCCGAGCTG-3' & & & \\
\hline OPA-03 & $5^{\prime}$-AGTCAGCCAC-3' & & & \\
\hline OPA-04 & $5^{\prime}$-AATCGGGCTG-3' & & & \\
\hline OPA-05 & $5^{\prime}$-AGGGGTCTTG-3' & & & \\
\hline OPA-06 & $5^{\prime}$-GGTCCCTGAC-3' & & & \\
\hline OPA-09 & $5^{\prime}$-GGGTAACGCC-3' & & & \\
\hline OPA-13 & $5^{\prime}-\mathrm{CAGCACCCAC}-3^{\prime}$ & & & \\
\hline OPA-18 & 5'-AGGTGACCGT-3' & & & \\
\hline OPB-15 & $5^{\prime}$-GGAGGGTGTT-3' & & & \\
\hline OPC-06 & $5^{\prime}$-AAGACCCCTC-3' & & & \\
\hline OPD-13 & $5^{\prime}$-GGGGTGACGA-3' & & & \\
\hline OPG-06 & $5^{\prime}$-GTGCCTAACC-3' & & & \\
\hline OPG-08 & $5^{\prime}$-TCACGTCCAC-3' & & & \\
\hline OPK-16 & $5^{\prime}$-GAGCGTCGAA-3' & & & \\
\hline $\mathrm{D} 2 \mathrm{~A}$ & 5'-ACAAGTACCGTGAGGGAAAGTTG-3' & \multirow{2}{*}{$\begin{array}{l}\text { 28S-rDNA universal } \\
\text { primers }\end{array}$} & \multirow{2}{*}{$780 \mathrm{bp}$} & \multirow{2}{*}[16]{} \\
\hline D3B & 5'-TCGGAAGGAACCAGCTACTA-3' & & & \\
\hline TW81 & 5'-GTT TCC GTA GGT GAA CCT GC-3' & \multirow{2}{*}{$\begin{array}{l}\text { rDNA-ITS universal } \\
\text { primers }\end{array}$} & \multirow{2}{*}{$1027-1045 \mathrm{bp}$} & \multirow{2}{*}{ [42] } \\
\hline AB28 & 5'-ATA TGC TTA AGT TCA GCG GGT-3' & & & \\
\hline SHF6 & 5'-GTTCTTACGTTACTTCCA-3' & Specific primer & \multirow[b]{2}{*}{$255 \mathrm{bp}$} & \multirow[b]{2}{*}[12]{} \\
\hline rDNA2 & 5'-TTTCACTCGCCGTTACTAAGG-3' & $\begin{array}{l}\text { rDNA-ITS universal } \\
\text { primer }\end{array}$ & & \\
\hline OPA06-HsF & 5'-GGACCCTGACGACCAGAATA-3' & \multirow{2}{*}{ SCAR primers } & \multirow{2}{*}{$922 \mathrm{bp}$} & \multirow{2}{*}{ This study } \\
\hline OPA06-HsR & $5^{\prime}$-GACAACACGAAGGAGCGAGC-3' & & & \\
\hline
\end{tabular}




\subsection{SCAR Primer Design}

Based on the results of initial RAPD-PCR-analysis, a prominent candidate band amplified by primer OPA 06 that clearly distinguished the SBCN from the other 3 tested cyst nematode species, was selected for the development of the SCAR marker. The band was purified and cloned into the pMD19-T vector (Takara-Bio, Shiga, Japan). Sequencing was performed by Shanghai Sangon Co., Ltd., and the sequences were analyzed using BLAST on the NCBI website [43]. The sequences alignment analysis was performed with MEGA X [44]. A set of specific SCAR primers OPA6-HsF and OPA6-HsR was designed using Primer 6.0 and tested on NCBI with Primer-BLAST program (http:/ / www.ncbi.nlm. nih.gov/tools/primer-blast, accessed on 14 August 2021).

\subsection{Specificity Test of SCAR Primer}

Nine populations of $H$. schachtii collected from Germany, Turkey, Belgium, China, and another 17 plant nematode species were used for SCAR primers specificity analysis. The PCR amplification reaction was carried out as follows: $50-\mu \mathrm{L}$ reaction contained $5 \mu \mathrm{L} 10 \times$ PCR buffer, $4 \mu \mathrm{L} 2.5 \mathrm{mM}$ dNTPs, $1 \mathrm{U}$ ExTaq DNA polymerase (Takara-Bio, Shiga, Japan), $0.6 \mu \mathrm{L}$ of $10 \mu \mathrm{M}$ each pair of SCAR primers (OPA06-HsF/OPA06-HsR), $0.6 \mu \mathrm{L}$ of $10 \mu \mathrm{M}$ each pair of universal primer (D2A/D3B), $1 \mu \mathrm{L}$ template DNA, and $37.6 \mu \mathrm{L}$ of $\mathrm{ddH}_{2} \mathrm{O}$. The PCR was performed under the following conditions: The thermocycler was programmed for $5 \mathrm{~min}$ at $95{ }^{\circ} \mathrm{C}, 35$ cycles of $30 \mathrm{~s}$ at $95^{\circ} \mathrm{C}, 40 \mathrm{~s}$ at $56^{\circ} \mathrm{C}, 1 \mathrm{~min}$ at $72{ }^{\circ} \mathrm{C}$, followed by $10 \mathrm{~min}$ at $72{ }^{\circ} \mathrm{C}$, and stored at $4{ }^{\circ} \mathrm{C}$. PCR products were analyzed by electrophoresis previously described. The experiment was repeated three times to confirm the result.

To evaluate the specificity of SCAR-PCR from mixed populations, first, a single cyst of SBCN (HS2) was mixed with other cyst nematode species Heterdera and Globodera genus (Groups 1 and 2). The RAPD sequences blast result shows that the sequences have homology with several Meloidogyne species. Thus, the treatment group comprises a mixture of root-knot nematodes including a single female of M. enterolobii, M. incognita, M. hapla, and M. graminicola together with a cyst of SBCN (Group 3). Finally, the D. ditylenchus species was always found in the sugar beet planting area in China; therefore, this species was also included (Group 4). The H. schachtii was absent from those groups that were used as the control (Groups 5, 6, 7. and 8). The specific treatments were listed in Table 3.

Table 3. Group treatments of $H$. schachtii with other related species.

\begin{tabular}{clc}
\hline Treatments & \multicolumn{1}{c}{ Mixed Populations } & Detection Results \\
\hline Group 1 & H. schachtii, H. glycines, H. sojae, H. avenae and H. flipjevi & + \\
\hline Group 2 & H. schachtii, G. rostochiensis and G. pallida & + \\
\hline Group 3 & H. schachtii, M. enterolobii, M. incognita, M. hapla and M. graminicola & + \\
\hline Group 4 & H. schachtii, D. ditylenchus & + \\
\hline Group 5 & H. glycines, H. avenae, H. flipjevi, G. pallida and G. rostochiensis & - \\
\hline Group 7 & M. enterolobii, M. incognita, M. hapla and M. graminicola & - \\
\hline Group 8 & D. ditylenchus & + \\
\hline Positive Control & H. schachtii & \\
\hline
\end{tabular}

\subsection{SCAR Primer Sensitivity Test}

To determine the sensitivity of the specific primers, DNA of a single cyst and a single juvenile were diluted in a certain proportion respectively, and ten-fold serial dilution of $H$. schachtii genome DNA (starting at $1000 \mathrm{ng} / \mu \mathrm{L}$ ) were prepared with dilution buffer (Takara-Bio, Shiga, Japan). DNA from a single cyst and a single J2 were serially diluted in 10-fold and 2-fold increments in sterile water (starting at $1 \mu \mathrm{L}$ DNA from a single cyst 
or J2, that is, $1 / 20$ a single cyst or J2), respectively. All different dilutions of DNA were used as DNA templates for SCAR-PCR reaction with OPA06-HsF and OPA06-HsR primers separately. The experiment was repeated three times for each sample.

\subsection{Duplex PCR Amplification}

In this present study, the universal primers D2A and D3B [16] were used to amplify a 780-bp fragment of the 28S rDNA gene to test the quality of the DNA template while amplifying specific fragments of the target nematode species from the non-target species using OPA06-HsF/OPA06-HsR primers. The PCR amplification reaction was performed as described above for the species-specific SCAR-PCR assay.

\subsection{Direct Detection of H. schachtii in Artificially Inoculated Plant Roots and Soil}

Sugar beet (cv. SD12830) and oilseed rape (cv. Deyou NO. 6), both of which are host plants of BCN, were planted in 250-mL plastic containers and cultured in the greenhouse. Two weeks later, $500 \mathrm{~J} 2 \mathrm{~s}$ were inoculated per plant, and the inoculated roots samples were collected separately at 3 days after inoculation (DAI), 9 DAI, and 15 DAI, respectively. For nematode assay, each sample was divided into two equal parts; one part $(0.1 \mathrm{~g})$ was used for counting the presence of nematodes in the inoculated root samples after staining with acid fuchsin. The remaining parts were stored at $-80^{\circ} \mathrm{C}$. A total of $0.1 \mathrm{~g}$ of the root was selected for DNA extraction, and three biological replicates were used for each treatment. Furthermore, 1, 5, 10, 25, and $50 \mathrm{~J} 2 \mathrm{~s}$ of sugar beet cyst nematode were hand-picked into $10 \mathrm{~g}$ of autoclaved sand soil. The genomic DNA isolated from the artificially inoculated soil samples were all used as templates to test the SCAR-PCR assay. The PCR amplification was performed using highly active KOD FX DNA polymerase (TOYOBO, Osaka, Japan) containing $50 \mu \mathrm{L}$ PCR reaction mixture: $2 \times$ KOD FX Buffer $25 \mu \mathrm{L}, 2 \mathrm{mM}$ dNTPs $10 \mu \mathrm{L}$, $10 \mu \mathrm{M}$ each primer $1.5 \mu \mathrm{L}$, template DNA $2.5 \mu \mathrm{L}, 1 \mathrm{U}$ KOD FX DNA polymerase, and $11 \mu \mathrm{L}$ distilled water. The thermocycler was run under the following conditions: $94^{\circ} \mathrm{C}$ for $2 \mathrm{~min}$, 40 cycles of $10 \mathrm{~s}$ at $98{ }^{\circ} \mathrm{C}, 40 \mathrm{~s}$ at $60{ }^{\circ} \mathrm{C}, 30 \mathrm{~s}$ at $68^{\circ} \mathrm{C}$, followed by $10 \mathrm{~min}$ at $68^{\circ} \mathrm{C}$, and stored at $4{ }^{\circ} \mathrm{C}$. The healthy root and autoclaved soil samples were used as negative controls. Additionally, the potential ability of the published specific primers SHF6 and rDNA2 [12] for direct detection of $H$. schachii from the plant or soil DNA was tested with the KOD FX DNA polymerase. The experiments were repeated three times.

\subsection{Direct Detection from Naturally Infected Roots and Soil Samples}

To evaluate the practical application of the SCAR primers, ten field samples, including sugar beetroots and rhizosphere soil, were collected from the counties surrounding Xinyuan County, Xinjiang province in June 2020. In addition, another five samples were also collected from Ermin County of Xinjiang and Inner Mongolia province in July 2021 (Table 4). These are the main sugar-beet-growing areas in China. Ten sugar beet roots together with approximately $500 \mathrm{~g}$ of rhizosphere soil samples were carefully collected from each sugar beet field surveyed and kept in the refrigerator at $4{ }^{\circ} \mathrm{C}$ for nematode assay. Ten grams $(10 \mathrm{~g})$ of soil together with one hundred milligrams $(100 \mathrm{mg})$ of sugar beet roots were randomly selected from each well-mixed sample for DNA extraction. Genome DNA extraction and SCAR-PCR detection with KOD FX DNA polymerase were performed as described above. As a comparison, numbers of SBCN were extracted and counted from each root $(0.1 \mathrm{~g})$ sample using the acid fuchsin staining method and cysts from $100 \mathrm{~g}$ soil sample using the floatation method. A single cyst was randomly picked from each sample, and the DNA was isolated and used as the templates for PCR amplification using previously developed specific- H. schachtii primers (SHF6 and rDNA2, Table 1) and rDNA-ITS universal primers (TW81 and AB28, Table 1) to confirm the results. The genomic DNA of SBCN and $\mathrm{ddH}_{2} \mathrm{O}$ was used as a positive and negative control, respectively. Each sample was repeated three times. 
Table 4. Detection of Heterodera schachtii in naturally infested field samples.

\begin{tabular}{|c|c|c|c|c|c|c|c|c|}
\hline \multirow{2}{*}{ Samples } & \multirow{2}{*}{ Host } & \multirow{2}{*}{ Location } & \multirow{2}{*}{ GPS } & \multirow{2}{*}{$\begin{array}{c}\text { Nematode } \\
\text { Density in Root a }\end{array}$} & \multirow{2}{*}{$\begin{array}{c}\text { Cyst } \\
\text { Density }\end{array}$} & \multicolumn{3}{|c|}{ Detection Results } \\
\hline & & & & & & SCAR-PCR & PCR & ITS-Sequencing \\
\hline 1 & \multirow{15}{*}{ Sugar beet } & $\begin{array}{l}\text { Huocheng County-1, } \\
\text { Xinjiang }\end{array}$ & $\begin{array}{l}\mathrm{N} 44^{\circ} 4^{\prime} 7^{\prime \prime} \\
\mathrm{E} 80^{\circ} 44^{\prime} 36^{\prime \prime}\end{array}$ & 0 & 0 & - & - & $\mathrm{N} / \mathrm{A}$ \\
\hline 2 & & $\begin{array}{l}\text { Huocheng County-2, } \\
\text { Xinjiang }\end{array}$ & $\begin{array}{l}\mathrm{N} 44^{\circ} 2^{\prime} 43^{\prime \prime} \\
\mathrm{E} 80^{\circ} 50^{\prime} 7^{\prime \prime}\end{array}$ & 0 & 0 & - & - & N/A \\
\hline 3 & & $\begin{array}{l}\text { Qapqal County-1, } \\
\text { Xinjiang }\end{array}$ & $\begin{array}{l}\mathrm{N} 43^{\circ} 45^{\prime} 50^{\prime \prime}, \\
\mathrm{E} 80^{\circ} 59^{\prime} 34^{\prime \prime}\end{array}$ & 0 & 4 & - & - & H. avenae \\
\hline 4 & & $\begin{array}{l}\text { Qapqal County-2, } \\
\text { Xinjiang }\end{array}$ & $\begin{array}{l}\mathrm{N} 43^{\circ} 46^{\prime} 26^{\prime \prime}, \\
\mathrm{E} 81^{\circ} 2^{\prime} 6^{\prime \prime}\end{array}$ & 0 & 0 & - & - & N/A \\
\hline 5 & & $\begin{array}{l}\text { Qapqal County-3, } \\
\text { Xinjiang }\end{array}$ & $\begin{array}{l}\mathrm{N} 43^{\circ} 45^{\prime} 40^{\prime \prime} \\
\mathrm{E} 81^{\circ} 9^{\prime} 18^{\prime \prime}\end{array}$ & 0 & 0 & - & - & N/A \\
\hline 6 & & $\begin{array}{l}\text { Xinyuan County-1, } \\
\text { Xinjian }\end{array}$ & $\begin{array}{l}\mathrm{N}^{2} 3^{\circ} 27^{\prime} 09^{\prime \prime}, \\
\mathrm{E} \\
82^{\circ} 59^{\prime} 56^{\prime \prime}\end{array}$ & $22 \pm 7$ & 132 & + & + & H. schachtii \\
\hline 7 & & $\begin{array}{c}\text { Xinyuan County-2, } \\
\text { Xinjian }\end{array}$ & $\begin{array}{l}\mathrm{N} 43^{\circ} 29^{\prime} 55^{\prime \prime} \\
\mathrm{E} 83^{\circ} 59^{\prime} 25^{\prime \prime}\end{array}$ & $44 \pm 6$ & 144 & + & + & H. schachtii \\
\hline 8 & & $\begin{array}{c}\text { Xinyuan County-3, } \\
\text { Xinjian }\end{array}$ & $\begin{array}{l}\mathrm{N} 43^{\circ} 44^{\prime} 67^{\prime \prime} \\
\mathrm{E} 83^{\circ} 06^{\prime} 39^{\prime \prime}\end{array}$ & $12 \pm 3$ & 287 & + & + & H. schachtii \\
\hline 9 & & $\begin{array}{c}\text { Xinyuan County-4, } \\
\text { Xinjian }\end{array}$ & $\begin{array}{l}\mathrm{N} 43^{\circ} 31^{\prime} 04^{\prime \prime}, \\
\mathrm{E} 83^{\circ} 11^{\prime} 13^{\prime \prime}\end{array}$ & $23 \pm 7$ & 92 & + & + & H. schachtii \\
\hline 10 & & $\begin{array}{c}\text { Xinyuan County-5, } \\
\text { Xinjian }\end{array}$ & $\begin{array}{l}\mathrm{N} 42^{\circ} 88^{\prime} 3252^{\prime \prime}, \\
\mathrm{E} 83^{\circ} 39^{\prime} 710^{\prime \prime}\end{array}$ & $33 \pm 5$ & 54 & + & + & H. schachtii \\
\hline 11 & & $\begin{array}{c}\text { Emin County-1, } \\
\text { Xinjiang }\end{array}$ & $\begin{array}{l}\mathrm{N} 46^{\circ} 46^{\prime} 460^{\prime \prime}, \\
\mathrm{E} 83^{\circ} 53^{\prime} 902^{\prime \prime}\end{array}$ & $8 \pm 3$ & 11 & + & + & H. schachtii \\
\hline 12 & & $\begin{array}{l}\text { Emin County-2, } \\
\text { Xinjiang }\end{array}$ & $\begin{array}{l}\mathrm{N} 46^{\circ} 46^{\prime} 468^{\prime \prime}, \\
\mathrm{E} 83^{\circ} 53^{\prime} 949^{\prime \prime}\end{array}$ & $45 \pm 11$ & 64 & + & + & H. schachtii \\
\hline 13 & & $\begin{array}{l}\text { Keyouqian Banner, } \\
\text { Inner Mongolia }\end{array}$ & N/A & 0 & 3 & - & - & H. avenae \\
\hline 14 & & $\begin{array}{l}\text { Urad Front Banner, } \\
\text { Inner Mongolia }\end{array}$ & N/A & 0 & 12 & - & - & H. glycines \\
\hline 15 & & $\begin{array}{l}\text { Linxi County, Inner } \\
\text { Mongolia }\end{array}$ & N/A & 0 & 9 & - & - & $\begin{array}{l}\text { H. avenae } \\
\text { H. glycines }\end{array}$ \\
\hline
\end{tabular}

${ }^{a}$ Numbers of Heterodera spp. counted after staining with acid fuchsin in $0.1 \mathrm{~g}$ sugar beet. ${ }^{\mathrm{b}}$ Numbers of cyst isolated and counted from $100 \mathrm{~mL}$ soil. N/A, no record.

\section{Results}

\subsection{RAPD-PCR and Sequences Analysis}

All the $H$. schachtii populations were used to test the 15 primers. The following primers, OPA01, OPA02, OPA03, OPA05, OPA09, OPA13, OPB15, OPD13, and OPK16, produced multiple RAPD amplification bands and the amplification results were unstable in the different populations, as shown in the repeated experiments. OPA06 can stably amplify 1000-bp bands from DNA samples of the H. schachti population, thus clearly distinguishing the SBCN from other tested cyst nematode species (Figure 1). The bands were purified, sequenced, and submitted to Genbank (Accession number MW854319). The Blastn results indicated that this sequence was similar to $H$. schachtii genomic sequences (GenBank accession No. JAHGVF010000211.1) and H. glycines genomic DNA sequences (VAPQ01000257.1) with 99.24\% and 86.35\% identity, respectively. The sequences also have homology (identity $<73 \%$ ) to genomic sequences of G. pallida (CBXT010012390.1), G. ellingtonae (MEIZ01000021.1), G. rostochiensis (JAEVLO010000036.1), M. incognita (RCFL01002996.1), M. arenaria (QEUI01000363.1), M. javanica (RCFK01013271.1), M. floridensis (RCFN01001171.1), and M. enterolobii (CAJEWN010003051.1) with low query cover $(<29 \%)$. The sequences alignment is shown in Figure S1. 


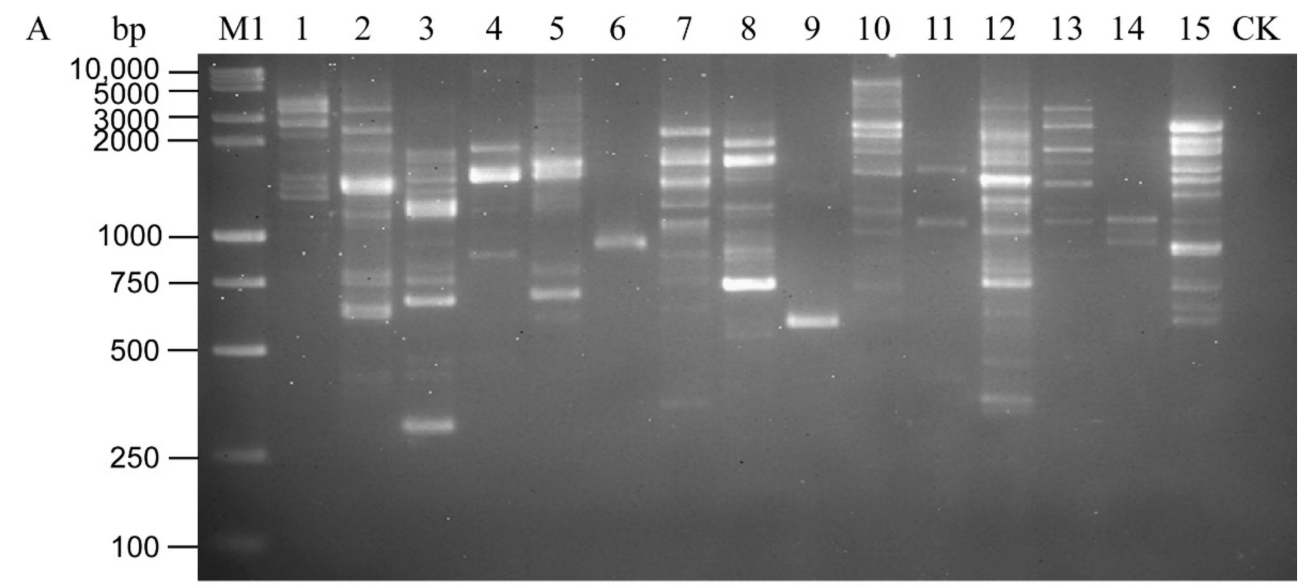

$\begin{array}{lllllllllll}\text { B } & \text { bp } & \text { M2 } & \mathrm{Hs} 01 & \mathrm{Hs} 02 & \mathrm{Hs} 06 & \mathrm{Hg} 01 & \mathrm{Hg} 02 & \mathrm{HsO} & \mathrm{Hc} & \mathrm{CK}\end{array}$

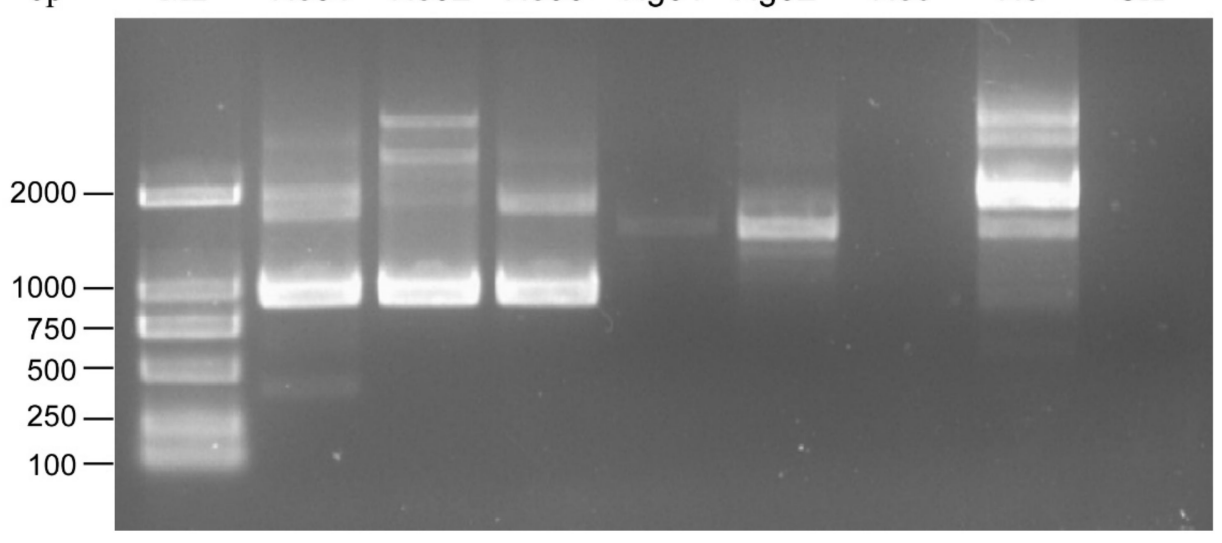

Figure 1. Amplification pattern of RAPD primers. (A) PCR results of Heterodra schachtii using 15 RAPD primers. (B) RAPD pattern of $H$. schachtii and H. glycines using Primer OPA06. 1-15: OPA01, OPA-02, OPA-3, OPA-04, OPA-05, OPA-06, OPA-09, OPA-13, OPA-18, OPB-15, OPC-06, OPD-13, OPG-06, OPG-08, and OPK-16. CK, negative control ( $\mathrm{ddH}_{2} \mathrm{O}$ instead of DNA). M1, DL10,000 + 2000 DNA Ladder; M2, D2000 DNA Ladder.

\subsection{Primers Design and Species-Specific Test}

A pair of specific SCAR primers OPA06-HsF/OPA06-HsR (Figure 1 and Table 1) was designed based on the sequence dissimilarity to $H$. schachtii and other related nematode species (Figure S1). The primer-BLAST result showed that the primer pair (OPA06-HsF and OPA06-HsR, Table 2) was specific to the OPA06 fragment, as no other targets were found in the Nr database. All the DNA samples were tested, and a specific band of $922 \mathrm{bp}$ was only obtained from $H$. schachtii populations. The duplex PCR with samples containing specimens of the $H$. schachtii populations yielded two distinct fragments of $922 \mathrm{bp}$ and $780 \mathrm{bp}$, respectively. In contrast, a single fragment of $780 \mathrm{bp}$ was also obtained from other nematode samples tested (Figure 2A). The PCR amplification with DNA templates from mixed populations showed that the positive bands were observed from the samples containing SBCN (Figure 2B). 


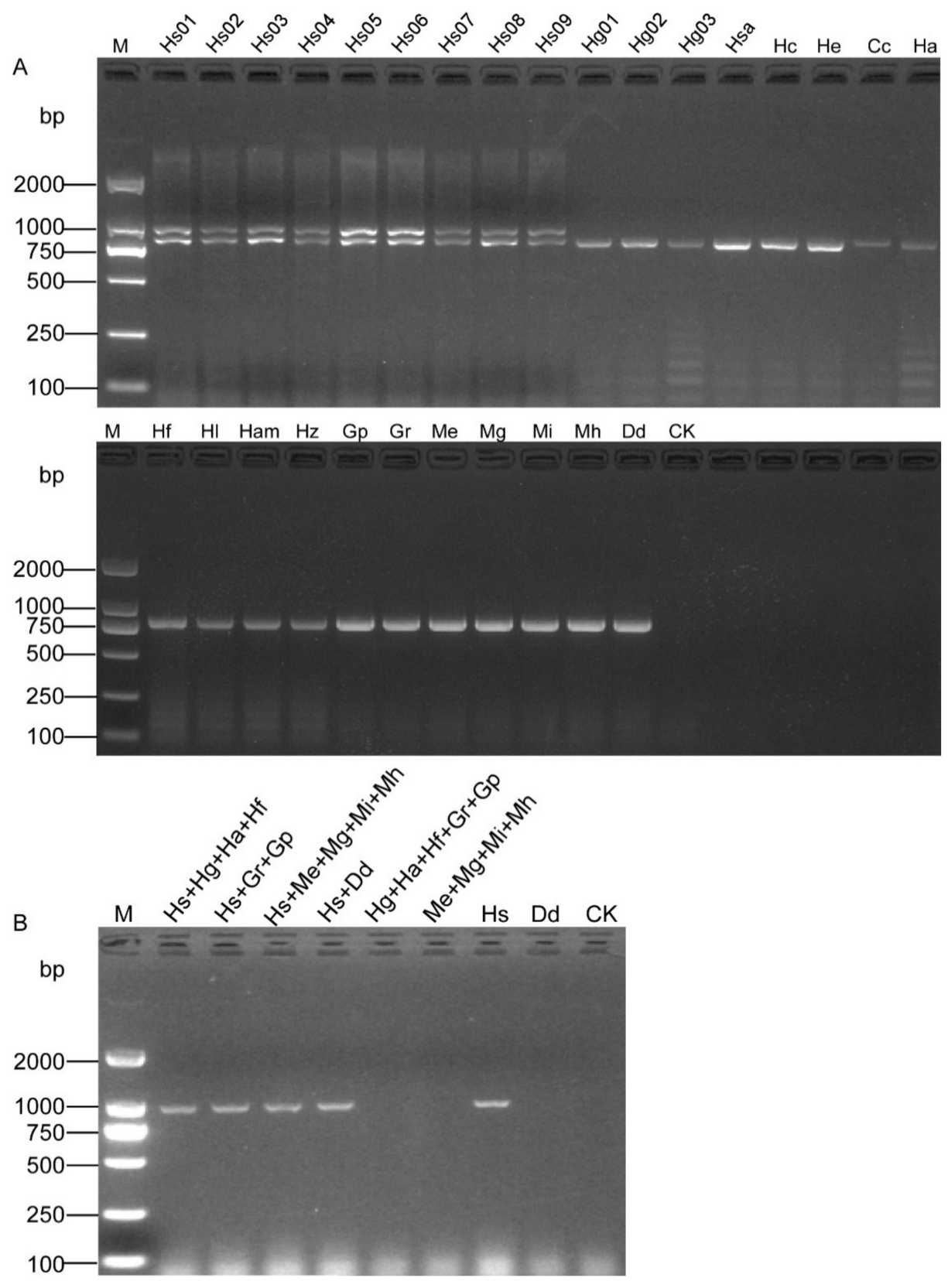

Figure 2. Specificity assessment of the SCAR marker for the detection of SBCN. (A) Duplex PCR results of SCAR and D2A/D3B primers. Two bands of $922 \mathrm{bp}$ and $780 \mathrm{bp}$ were observed from nine populations of $H$. schachtii (Hs01-Hs09), and a single fragment of $780 \mathrm{bp}$ was obtained from other nematode samples (Hg01, Hg02, Hg03, Hso, Hc, He, Cc Ha, Hf, Hl, Ha, Hz, Gr, Gp Mi, Me, Mh, $\mathrm{Mg}$, and Dd). (B) PCR products from mixed populations using the SCAR-PCR. CK, negative control ( $\mathrm{ddH}_{2} \mathrm{O}$ instead of DNA). M, D2000 DNA Ladder.

\subsection{Sensitivity Test}

The PCR results showed that the SCAR-PCR assay could detect $H$. schachtii as low as $10^{-2} \mu \mathrm{L}$ DNA from a single cyst and $1 / 16 \mu \mathrm{L}$ DNA from a single $\mathrm{J} 2$, that is, $5 \times 10^{-4}$ of a cyst and $1 / 320$ of a 2 in the reaction mixture (Figure 3A,B). Quantitative DNA templates were also used and the results showed that visible bands could be amplified at a DNA concentration of even as low as $10 \mathrm{pg} / \mu \mathrm{L}$ (Figure 3C). 


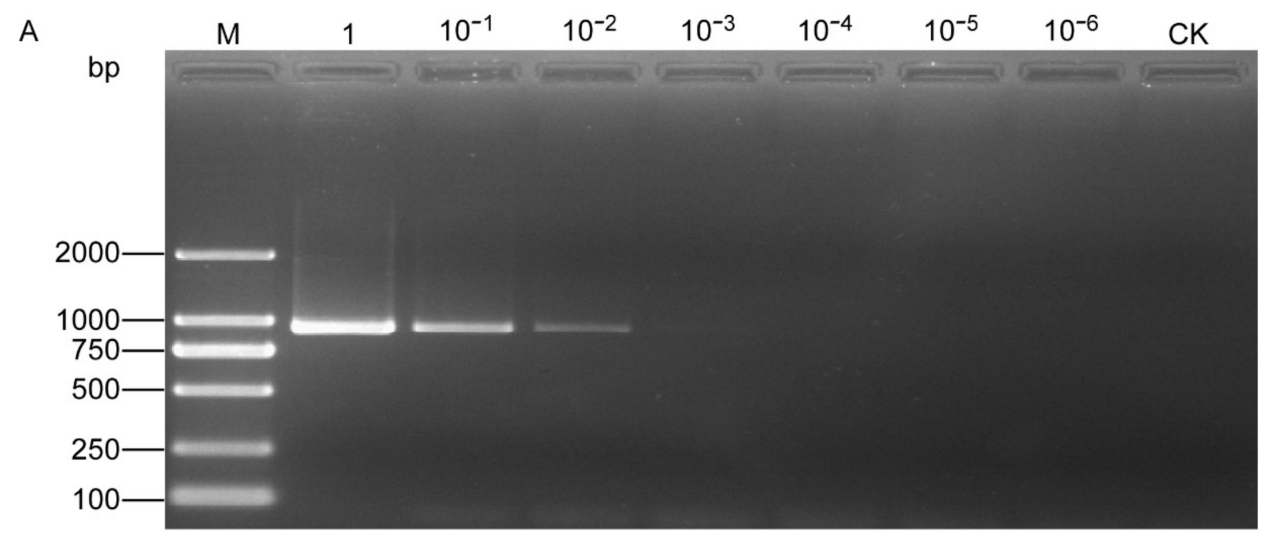

B

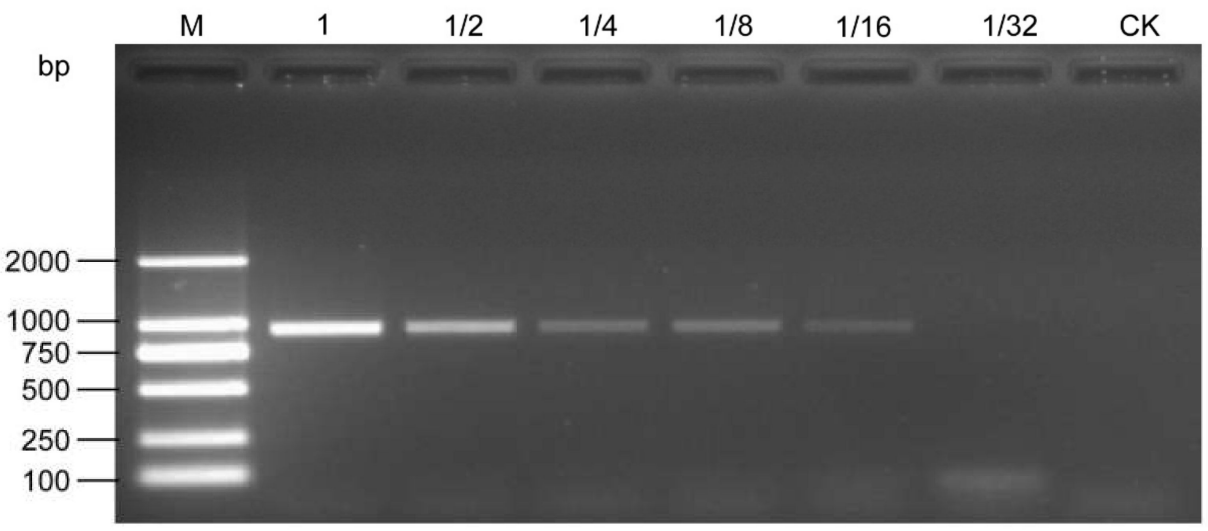

C

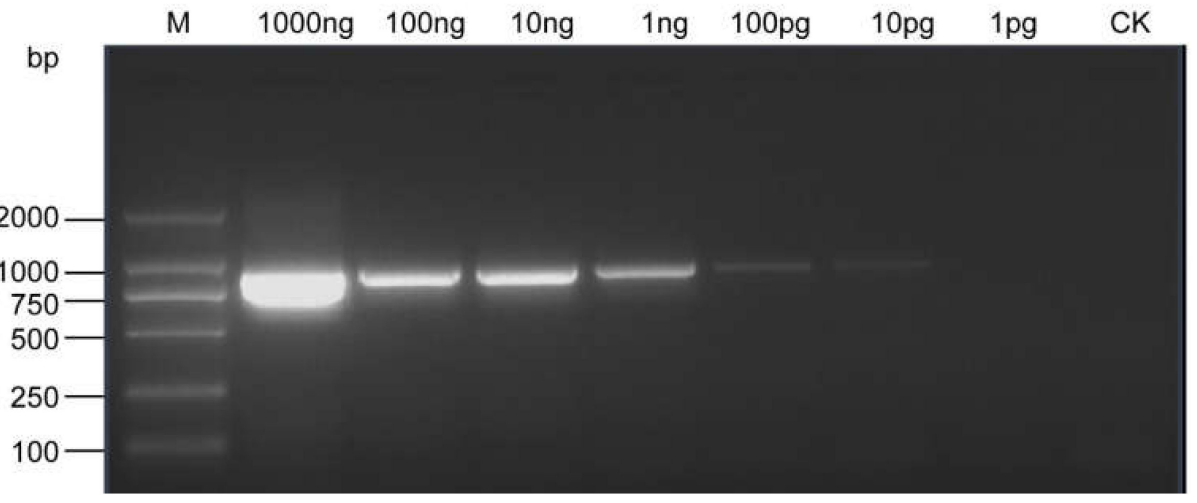

Figure 3. Sensitivity assessment of the SCAR-PCR method for the detection of H. schachtii. (A) Performed with serial dilution of DNA from a single cyst; (B) performed with serial dilution of DNA from a single second-stage juvenile; $(\mathrm{C})$ sensitivity test with serial dilution of a genomic DNA template. M, D2000 DNA Ladder; CK, negative control ( $\mathrm{ddH}_{2} \mathrm{O}$ instead of DNA).

\subsection{Direct Detection of H. schachtii in Inoculated Plant Roots and Soil}

The SCAR-PCR test results indicated that positive bands of $922 \mathrm{bp}$ were observed in all root samples inoculated by SBCN (Figure 4A). Moreover, numerous $H$. schachtii were observed in the remaining part of the root samples after staining with acid fuchsin (Figure 4B). Additionally, the SCAR-PCR assay can accurately detect one J2 per $10 \mathrm{~g}$ of soil sample. Negative results were obtained from the non-inoculated root and autoclaved soil sample (Figure 4C). In addition, the potentiality of the published species-specific primer SHF6/rDNA2 was not performed using genomic DNA extracted from plant roots and soil samples (Figure S2). 

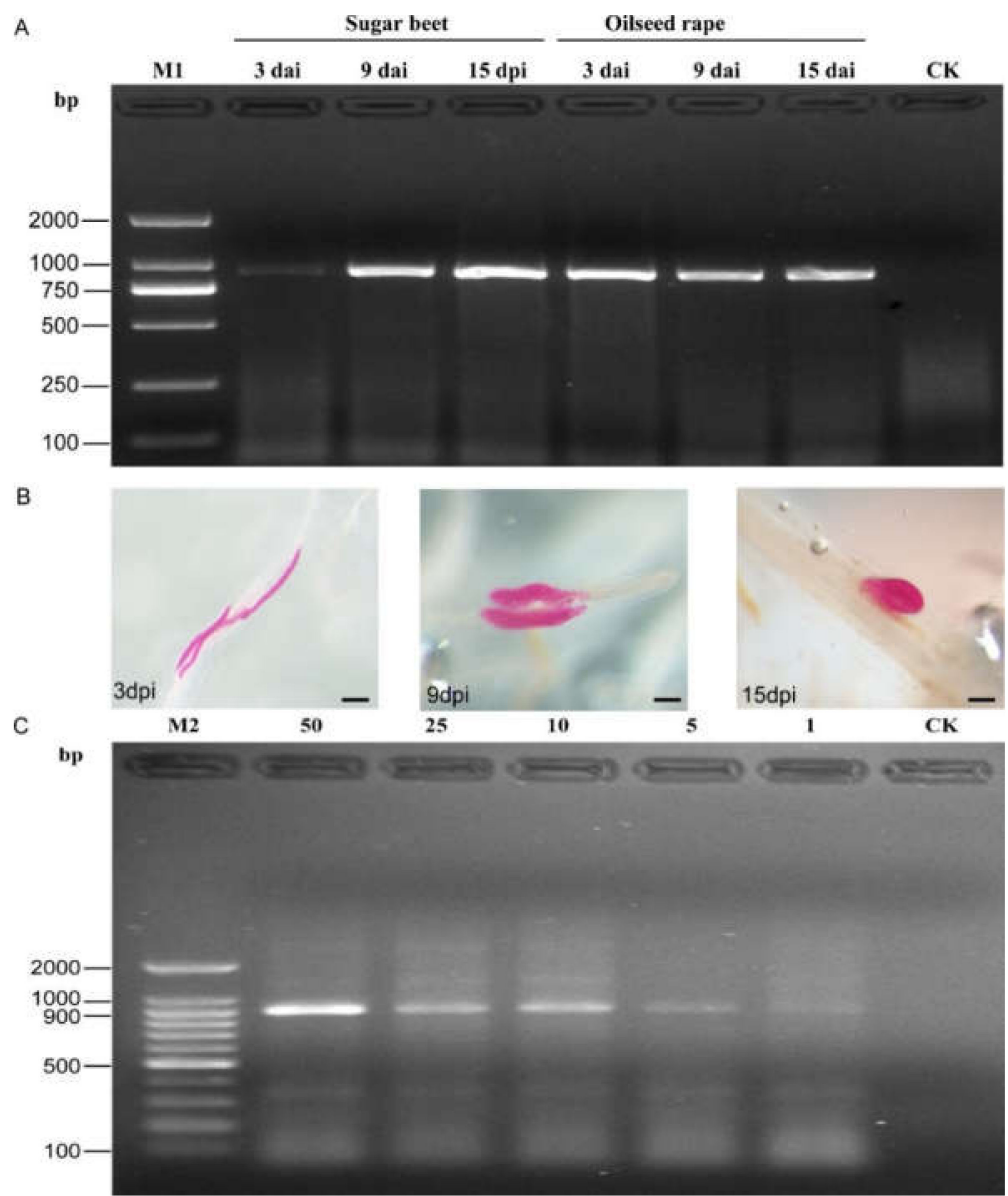

Figure 4. PCR products from inoculated roots and soil samples using the SCAR-PCR method. (A) PCR performed at 3 days, 9 days, and 15 days after inoculation (DAI) with $H$. schachtii using SCAR marker; Non-inoculated roots as the control; (B) H. schachtii developing stages in sugar beet roots at 3,9, and 15 DAI (stained), bar $=100 \mu \mathrm{m}$; (C) detection of $H$. schachtii from DNA extracts from $50,25,10,5$, and $1 \mathrm{~J} 2 \mathrm{~s}$ in $10 \mathrm{~g}$ of soil; autoclaved soil as the control (CK). M1, D2000 DNA ladder; M2, 100-bp DNA ladder.

\subsection{Direct Detection of Naturally Infected Root and Soil Samples}

A 922-bp band was observed in seven root samples from Xinyuan and Ermin Counties of Xinjiang Province. No bands were obtained from the other eight field samples and negative control (Figure 5A). Moreover, the detection results of soil samples from the same locations were consistent with those of roots (Figure 5B), which showed that the SCAR primers could effectively detect SBCN from the field samples. The results were confirmed by the developed specific primers with the DNA template from a single cyst (Figure 5C and Table 4). 


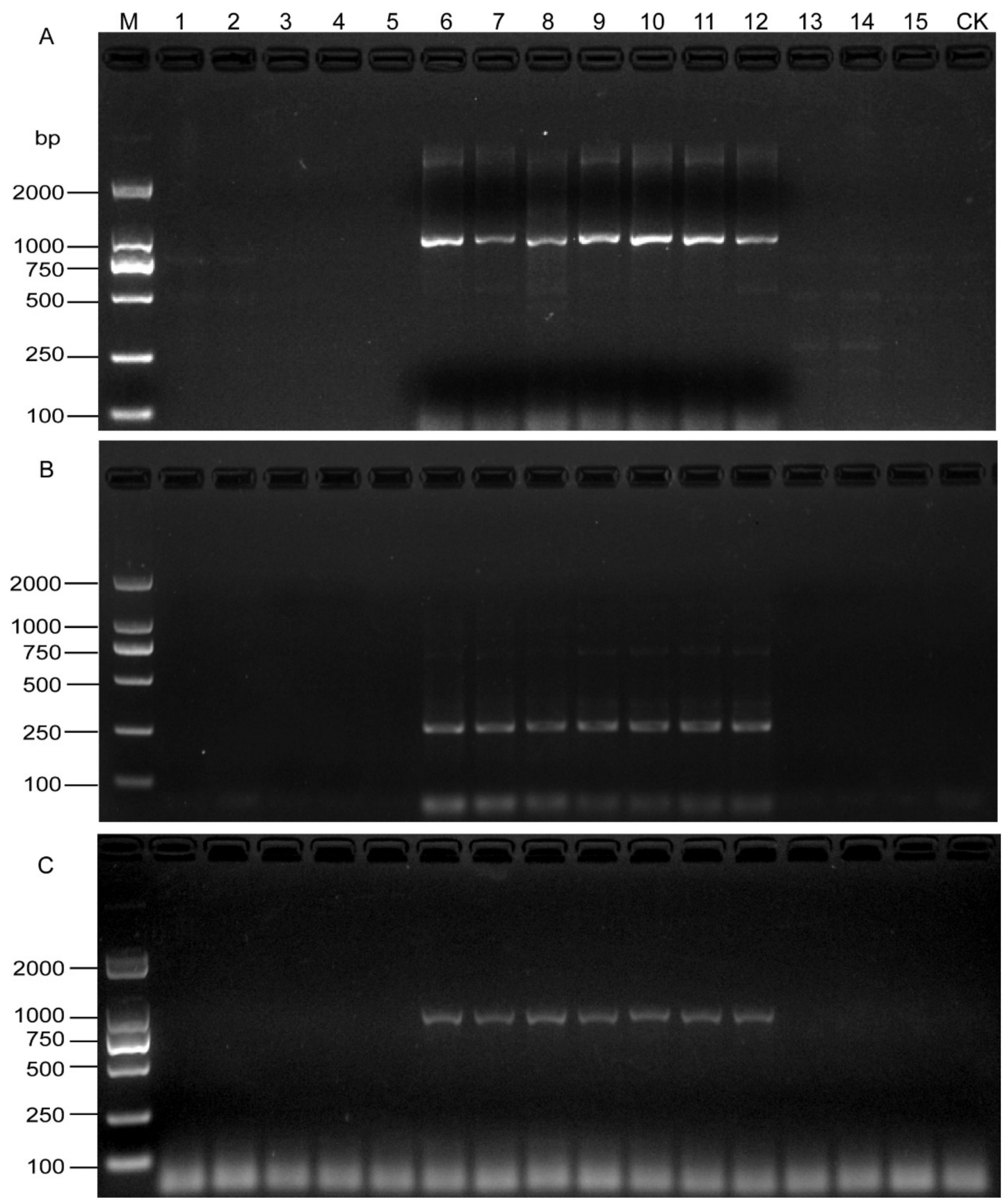

Figure 5. PCR products from naturally infested field root and soil samples using the SCAR-PCR method. (A) Detection of $H$. schachtii from root using SCAR primers. (B) Detection of $H$. schachtii from cyst using SHF6 and rDNA2 primers. (C) Direct detection of $H$. schachtii from field soil samples using SCAR primers. M, D2000 DNA Ladder; CK, Negative control.

\section{Discussion}

SBCN infects a wide spectrum of hosts, posing a severe economic threat to sugar beet production worldwide $[6,7,45]$. This species has been recognized as a quarantine nematode in China and some other countries; unfortunately, it was recently discovered in Xinyuan county Xinjiang province, China [26]. For management decisions, an effective and reliable diagnostic assay to detect the presence of SBCN in root and soil is important. In this present study, based on the amplification sequence of the RAPD primer OPA06, a set of species-specific SCAR primers for SBCN detection was developed in the current study. The assay was highly specific and able to distinguish $H$. schachtii from other morphologically similar Heterodera spp. and other nematodes species. Furthermore, the assay was 
validated using artificially and naturally infested roots and soils with varying $H$. schachtii population densities.

To estimate the specificity of the SCAR-PCR assay developed in this study, the blast search results indicated that the sequence was similar to $H$. glycines with $86.35 \%$ identity. Previous reports have shown that $H$. schachtii and $H$. glycine diverged from a common ancestor and to be sibling species within the same taxonomic subgroup (schachtii). Thus, it was a great challenge to differentiate $H$. schachtii and $H$. glycine due to their similarity and close relationship [29]. Conversely, a specific band was also obtained in only nine populations of H. schachtii isolated from four different countries (Germany, Turkey, Belgium, and China) while the negative results were obtained from 19 isolates belonging to 10 closely related cyst nematodes and other five nematode species. The results show that our developed primers of $H$. schachtii have been proven to be exceptionally specific when tested with template DNA of the aforementioned isolates. Even the primers developed in this study were selected in the specific genomic sequences where there exist differences between $H$. schachtii and other cyst and related species (Figure 2); in the future, we recommend that more populations of $H$. schachtii and other closely related cyst nematode species should be tested to avoid the risk of misidentification.

This sensitivity detection of our developed assay was higher than previous reports for SBCN identification. Amiri et al. [12] could detect $0.6 \mathrm{ng}$ genomic DNA or DNA of $1 / 1000$ cyst of $H$. schachtii using a species-specific primer set designed from ITS regions. Furthermore, Madani et al. [13] also report that the sensitivity of their real-time PCR diagnostic tool for $\mathrm{H}$. schachtii detection was lower than $100 \%$ for samples containing fewer than five J2; however, a single J2 and three J2 were detected in only 20 and $60 \%$ of the samples, respectively, the limit of detection was consistent with the results of Gamel et al. [15]. In contrast, the SCAR-PCR assays developed in the present study were sensitive enough to detect as low as 1/320 of a J2 of $H$. schachtii, even if the quantitative PCR is an advancement of the conventional PCR method.

To evaluate the practical application of the SCAR primers for direct detection of SBCN from the infested root and soil samples, the result shows that the nematodes were successfully amplified from two infected plant roots at 3, 9, and 15 DAI. Microscopic observations also show that $H$. schachtii becomes parasitic during the following growth stages: J2 at third stage (J3) and adult females at 3, 9, and 15 DAI, respectively. These diagnostic observations reported in this study indicate that SBCN could be detected at different growth stages in sugar beet and oilseed rape roots. The same scenario was also reported for the detection of cereal cyst nematode $H$. filipjevi [24] and false root-knot nematode Nacobbus species [46]. Additionally, this SCAR assay can accurately identify one $\mathrm{J} 2 \mathrm{~g}$ H. schachtii in $10 \mathrm{~g}$ of the soil sample, equivalent to $20 \mathrm{SBCN}$ juveniles/200 $\mathrm{g}$ of soil. It is consistent with the previous report for detection of H. glycines using SCAR-PCR assay [15] but higher than those previously reported. Ophel-Keller et al. [47] detected fewer than one egg of H. avenae per gram of soil by real-time PCR. Peng et al. [24] were also able to detect single juveniles of $\mathrm{H}$. filipjevi per $0.5 \mathrm{~g}$ of soil equivalent to 400 juveniles $/ 200 \mathrm{~g}$ of soil. However, the potentiality of the previously published species-specific primer SHF6/rDNA2 for H. schachii detection was not performed in this study using genomic DNA extracted from plant root and soil samples either with Taq DNA polymerase or KOD FX DNA polymerase (Figure S2). This implies that, if the reported primers were to be used, more time will be spent to isolate the target nematode from the soil samples. Interestingly, the SCAR-PCR assay developed in this study was able to overcome such limitations and thus shows high detection sensitivity to SBCN. Our results indicated that the SCAR method can serve as a detection tool to diagnose early SBCN infection in the plant root and field soils, where there is absolutely no visual symptom of infection.

The SCAR-PCR assay was also validated by testing its SBCN detection in 15 naturally infested sugar beet root and soil samples. The positive results were observed in seven beet root samples from Xinyuan and Ermin Counties of Xinjiang Province but absent in other eight field samples from Huocheng and Qapqal Counties of Xinjiang and three counties 
of Inner Mongolia. The results indicated that the presence of the SBCN has now been confirmed in Xinyuan and Ermin County of Xinjiang Province; however, its distribution in China is limited based on the present report [26]. H. schachtii is an economically important plant-parasitic nematode that limits sugar beet production worldwide; thus, it has now been recognized and listed as a quarantine pest in China. Furthermore, Xinjiang province is one of the major sugar beet cultivation areas in China; therefore, strict control measures should be taken to prevent further spread of the nematode to other beet growing areas of the country.

\section{Conclusions}

This study presents the first protocol using a species-specific SCAR-PCR assay to detect $H$. schachtii directly from artificially and naturally infested root and soil samples of sugar beet plants. The SCAR-PCR assay will also be useful for discriminating H. schachtii from mixed populations of other cysts and non-cysts nematode species. It is simple, rapid, reliable, and accurate irrespective of the life stage and abundance of the nematode and has lower requirements for experimental conditions. Therefore, the assay eliminates the time-consuming stages of traditional nematode extraction, microscopic identification, and counting and requires no prior knowledge of nematode taxonomy or morphology. It can be used not just in research but also in diagnostic laboratories, infested fields, and pest management extension services in China.

Supplementary Materials: The following are available online at https://www.mdpi.com/article/10 .3390 /life11121358/s1, Figure S1: sequences alignment between H. schachtii and other homologous nematodes. HS-OPA06: H. schachtii (GenBank accession No. MW854319); Hsc_scaff211: H. schachtii (JAHGVF010000211.1); Hg_X12_chr4: H. glycines (VAPQ01000257.1); Gr_Scaffold36: G. rostochiensis (JAEVLO010000036.1); Gpal_scaffold_689_contig_3: G. pallida (CBXT010012390.1); Ge_scaf_0021: G. ellingtonae (MEIZ01000021.1); Mi_W1_scaffold8403_cov70: M. incognita (RCFL01002996.1); Ma_A20_rig00001048: M. arenaria (RCFL01000363.1); Mj_VW4_scaffold15760_cov276: M. javanica (RCFK01013271.1); Me_Ment3s03051: M. enterolobii (CAJEWN010003051.1). Figure S2: PCR amplification products from inoculated roots and soil samples using published PCR assay with SHF6 and rDNA2 primers.

Author Contributions: Conceptualization, H.P. and D.P.; methodology, C.J. and Y.Z.; validation, H.P.; formal analysis, C.J. and K.Y.; investigation, Y.Z.; resources, G.L., H.G. and K.L.; data curation, C.J. and Y.Z.; writing — original draft preparation, C.J., Y.Z. and S.A.; writing—review and editing, L.K. and W.H.; supervision, H.P. and D.P.; project administration, H.P.; funding acquisition, H.P. All authors have read and agreed to the published version of the manuscript.

Funding: This research was funded by the National Natural Science Foundation of China, grant number 31972247 and 31672012, the Open Fund of Key Laboratory of Integrated Pest Management on Crop in Northwestern Oasis, Ministry of Agriculture, grant number KFJJ202101, the Science and Technology Innovation Project of Chinese Academy of Agricultural Sciences, and the earmarked fund for China Agriculture Research System, grant number CARS170307.

Institutional Review Board Statement: Not applicable.

Informed Consent Statement: Not applicable.

Data Availability Statement: The original contributions presented in the study are included in the article. Further inquiries can be directed to the corresponding author/s.

Acknowledgments: We thank Maurice Mones (Institute for Agriculture and Fisheries Research (ILVO), Belgium) for providing experimental materials.

Conflicts of Interest: The authors declare no conflict of interest. 


\section{References}

1. Muller, J. The economic importance of Heterodera schachtii in Europe. Helminthologia 1999, 36, $205-213$.

2. Jones, J.T.; Haegeman, A.; Danchin, E.G.; Gaur, H.S.; Helder, J.; Jones, M.G.; Kikuchi, T.; Manzanilla-Lopez, R.; Palomares-Rius, J.E.; Wesemael, W.M.; et al. Top 10 plant-parasitic nematodes in molecular plant pathology. Mol. Plant Pathol. 2013, 14, 946-961. [CrossRef] [PubMed]

3. Cooke, D. Nematode parasites of sugarbeet. In Plant Parasitic Nematodes in Temperate Agriculture; Evans, K., Trudgill, D.L., Webster, J.M., Eds.; CAB International: Wallingford, UK, 1993; pp. 133-169.

4. Evans, K.; Rowe, J.A. Distribution and economic importance. In The Cyst Nematodes; Sharma, S.B., Ed.; Kluwer Academic Publishers: London, UK, 1998; pp. 1-30. [CrossRef]

5. Steele, A.E. The host range of the sugar beet nematode, Heterodera schachtii Schmidt. J. Am. Soc. Sugar Beet Technol. 1965, 13, 573-603. [CrossRef]

6. Kim, D.H.; Cho, M.R.; Yang, C.Y.; Kim, H.H.; Yoon, J.B. Host Range Screening of the Sugar Beet Nematode, Heterodera schachtii Schmidt. Korean J. Appl. Entomol. 2016, 55, 389-403. [CrossRef]

7. Kim, J.; Ni, G.; Kim, T.; Chun, J.Y.; Kern, E.M.A.; Park, J.K. Phylogeography of the highly invasive sugar beet nematode, Heterodera schachtii (Schmidt, 1871), based on microsatellites. Evol. Appl. 2019, 12, 324-336. [CrossRef]

8. Subbotin, S.A.; Waeyenberge, L.; Moens, M. Identification of cyst forming nematodes of the genus Heterodera (Nematoda: Heteroderidae) based on the ribosomal DNA-RFLP. Nematology 2000, 2, 153-164. [CrossRef]

9. Caswell-Chen, E.P.; Williamson, V.M.; Wu, F.F. Random Amplified Polymorphic DNA Analysis of Heterodera cruciferae and H. schachtii populations. J. Nematol. 1992, 24, 343-351. [PubMed]

10. Madani, M.; Kyndt, T.; Colpaert, N.; Subbotin, S.A.; Gheysen, G.; Moens, M. Polymorphism among sugar beet cyst nematode Heterodera schachtii populations as inferred from AFLP and ITS rDNA gene analyses. Russ. J. Nematol. 2007, 15, 117-128.

11. Moens, M.; Subbotin, S.; Maafi, Z.T. Molecular identification of cyst-forming nematodes (Heteroderidae) from Iran and a phylogeny based on ITS-rDNA sequences. Nematology 2003, 5, 99-111.

12. Amiri, S.; Subbotin, S.A.; Moens, M. Identification of the beet cyst nematode Heterodera schachtii by PCR. Eur J. Plant. Pathol. 2002, 108, 497-506. [CrossRef]

13. Madani, M.; Subbotin, S.A.; Moens, M. Quantitative detection of the potato cyst nematode, Globodera pallida, and the beet cyst nematode, Heterodera schachtii, using Real-Time PCR with SYBR green I dye. Mol. Cell. Probes 2005, 19, 81-86. [CrossRef] [PubMed]

14. Toumi, F.; Waeyenberge, L.; Viaene, N.; Dababat., A.; Nicol, J.M.; Ogbonnaya, F.; Maurice Moens, M. Development of a speciesspecific PCR to detect the cereal cyst nematodes Heterodera avenae and Heterodera filipjevi. Eur. J. Plant Pathol. 2013, 136, 613-624. [CrossRef]

15. Gamel, S.; Letort, A.; Fouville, D.; Folcher, L.; Grenier, E. Development and validation of real-time PCR assays based on novel molecular markers for the simultaneous detection and identification of Globodera pallida, G. rostochiensis and Heterodera schachtii. Nematology 2017, 19, 789-804. [CrossRef]

16. Subbotin, S.A.; Peng, D.L.; Moens, M. A rapid method for the identification of the soybean cyst nematode Heterodera glycines using duplex PCR. Nematology 2001, 3, 365-371. [CrossRef]

17. Yan, G.P.; Smiley, R.W.; Okubara, P.A.; Skantar, A.M. Species-Specific PCR Assays for Differentiating Heterodera filipjevi and H. avenae. Plant Dis. 2013, 97, 1611-1619. [CrossRef]

18. Lax, P.; Duenas, J.C.R.; Gardenal, C.N.; Doucet, M.E. Genetic variability estimated with RAPD-PCR markers in two populations of Heterodera glycines Ichinohe, 1952 (Nematoda: Heteroderidae) from Argentina. Nematology 2004, 6, 13-21. [CrossRef]

19. da Silva, A.T.; Penna, J.C.V.; Goulart, L.R.; Dos Santos, M.A.; Arantes, N.E. Genetic variability among and within races of Heterodera glycines Ichinohe assessed by RAPD markers. Genet. Mol. Biol. 2000, 23, 323-329. [CrossRef]

20. Zhang, L.; Dean, R.A.; Knap, H.T.; Lewis, S.A. Diversity among a Heterodera glycines field isolate and derived inbreds based on RAPD analysis and reproduction on soybean genotypes. J. Nematol. 1998, 30, 477-484.

21. Fullaondo, A.; Barrena, E.; Viribay, M.; Barrena, I.; Salazar, A.; Ritter, E. Identification of potato cyst nematode species Globodera rostochiensis and G. pallida by PCR using specific primer combinations. Nematology 1999, 1, 157-163. [CrossRef]

22. Ye, W. Development of PrimeTime-Real-Time PCR for Species Identification of Soybean Cyst Nematode (Heterodera glycines Ichinohe, 1952) in North Carolina. J. Nematol. 2012, 44, 284-290.

23. Ou, S.Q.; Peng, D.L.; Liu, X.M.; Li, Y.; Moens, M. Identification of Heterodera glycines using PCR with sequence characterised amplified region (SCAR) primers. Nematology 2008, 10, 397-403. [CrossRef]

24. Peng, H.; Qi, X.L.; Peng, D.L.; Long, H.B.; He, X.F.; Huang, W.K.; He, W.T. Sensitive and Direct Detection of Heterodera filipjevi in Soil and Wheat Roots by Species-Specific SCAR-PCR Assays. Plant. Dis. 2013, 97, 1288-1294. [CrossRef]

25. Zhang, B.C.; Huang, Y.C. A list of important plant diseases in China. Rev. Plant Pathol. 1990, 63, 97-118.

26. Peng, H.; Liu, H.; Gao, L.; Jiang, R.; Li, G.K.; Gao, H.F.; Wu, W.; Wang, J.; Zhang, Y.; Huang, W.K.; et al. Identification of Heterodera schachtii on sugar beet in Xinjiang Uygur Autonomous Region of China. J. Integr. Agric. 2021. [CrossRef]

27. Samuelian, S.; Kleine, M.; Ruyter-Spira, C.P.; Klein-Lankhorst, R.M.; Jung, C. Cloning and functional analyses of a gene from sugar beet up-regulated upon cyst nematode infection. Plant. Mol. Biol. 2004, 54, 147-156. [CrossRef] [PubMed] 
28. Cui, J.K.; Erginbas-Orakci, G.; Peng, H.; Huang, W.K.; Liu, S.M.; Qiao, F.; Elekcioglu, I.H.; Imren, M.; Dababat, A.A.; Peng, D.L. First report of sugar beet nematode, Heterodera schachtii Schmidt, 1871 (Nemata: Heteroderidae) in sugar beet growing areas of Sanliurfa, Turkey. Turk. Entomol. Derg-Tu. 2016, 40, 303-314. [CrossRef]

29. Zhen, H.Y.; Peng, H.; Kong, L.A.; Hong, B.Y.; Zhu, G.L.; Wang, R.H.; Peng, D.L.; Wen, Y.H. Heterodera sojae, a New Cyst Nematode Record in China and Its Parasitism to Legume Crops. Sci. Agric. Sin. 2018, 51, 2913-2924. [CrossRef]

30. Cui, J.K.; Huang, W.K.; Peng, H.; Liu, S.M.; Wang, G.F.; Kong, L.A.; Peng, D.L. A new pathotype characterization of Daxing and Huangyuan populations of cereal cyst nematode (Heterodera avenae) in China. J. Integr. Agric. 2015, 14, 724-731. [CrossRef]

31. Peng, D.L.; Ye, W.X.; Peng, H.; Gu, X.C. First Report of the Cyst Nematode (Heterodera filipjevi) on Wheat in Henan Province, China. Plant Dis. 2010, 94, 1262. [CrossRef]

32. Toumi, F.; Waeyenberge, L.; Viaene, N.; Dababat, A.; Nicol, J.M.; Ogbonnaya, F.; Moens, M. Development of a species-specific PCR to detect the cereal cyst nematode, Heterodera latipons. Nematology 2013, 15, 709-717. [CrossRef]

33. Ding, Z.; Namphueng, J.; He, X.F.; Peng, D.L.; Huang, W.K. First Report of the Cyst Nematode (Heterodera elachista) on Rice in Hunan Province, China. Plant Dis. 2012, 96, 151. [CrossRef] [PubMed]

34. Jiang, R.; Hu, X.; Li, Y.; Bian, Y.; Huang, L.; Gu, J.; Liu, P.; Huang, W.; Kong, L.; Liu, S.; et al. Heterodera amaranthusiae n. sp. (Nematoda: Heteroderidae), a new cyst nematode parasitising Amaranthus retroflexus L. in China. Nematology 2021, 1-17. [CrossRef]

35. Cui, J.; Zhou, B.; Jiao, Y.; Lv, Y.; Lu, J.; Meng, H.; Jiang, S. First Report of Heterodera zeae on Maize (Zea mays) in Henan Province, China. Plant Dis. 2020, 104, 2030. [CrossRef]

36. Ge, J.; Cao, A.; Chen, H.; Moens, M. Real time PCR assay of the golden nematode, Globodera rostochiensis with TaqMan probe. Plant Prot. 2009, 35, 105-109.

37. Duan, Y.X.; Wang, D.; Chen, L.J. First Report of the Cactus Cyst Nematode, Cactodera cacti, on Cactus in Northern China. Plant Dis. 2012, 96, 1385. [CrossRef] [PubMed]

38. Peng, H.; Long, H.; Huang, W.; Liu, J.; Cui, J.; Kong, L.; Hu, X.; Gu, J.; Peng, D. Rapid, simple and direct detection of Meloidogyne hapla from infected root galls using loop-mediated isothermal amplification combined with FTA technology. Sci. Rep. 2017, 7, 44853. [CrossRef]

39. Htay, C.; Peng, H.; Huang, W.K.; Kong, L.A.; He, W.T.; Holgado, R.; Peng, D.L. The development and molecular characterization of a rapid detection method for Rice root-knot nematode (Meloidogyne graminicola). Eur. J. Plant Pathol. 2016, 146, 281-291. [CrossRef]

40. Peng, H.; Peng, D.L.; Long, H.B.; He, W.T.; Qiao, F.; Wang, G.F.; Huang, W.K. Characterisation and functional importance of beta-1,4-endoglucanases from the potato rot nematode, Ditylenchus destructor. Nematology 2014, 16, 505-517. [CrossRef]

41. Amiri, S.; Subbotin, S.; Moens, M. Comparative morphometrics and RAPD studies of Heterodera schachtii and H. betae populations. Russ. J. Nematol. 2003, 11, 91-99.

42. Joyce, S.A.; Reid, A.; Driver, F.; Curran, J. Application of polymerase chain reaction (PCR) methods to identification of entomopathogenic nematodes. In COST 812 Biotechnology: Genetics of Entomopathogenic Nematode-Bacterium Complexes; Burnell, A.M., Ehlers, R.U., Masson, J.P., Eds.; European Commission: Brussels, Belgium, 1994; pp. 178-187.

43. McGinnis, S.; Madden, T.L. BLAST: At the core of a powerful and diverse set of sequence analysis tools. Nucleic Acids Res. 2004, 32, 20-25. [CrossRef] [PubMed]

44. Kumar, S.; Stecher, G.; Li, M.; Knyaz, C.; Tamura, K. MEGA X: Molecular Evolutionary Genetics Analysis across Computing Platforms. Mol. Biol. Evol. 2018, 35, 1547-1549. [CrossRef] [PubMed]

45. Subbotin, S.A.; Mundoocampo, M.; Baldwin, J.G.; Subbotin, S.A.; Mundoocampo, M.; Baldwin, J.G. Systematics of Cyst Nematodes (Nematoda: Heteroderinae). In Nematology Monographs and Perspectives Volume 8B; Hunt, D.J., Perry, R.N., Eds.; Koninklijke Brill NV: Leiden, The Netherlands, 2010; Volume 61, pp. 35-42.

46. Atkins, S.D.; Manzanilla-Lopez, R.H.; Franco, J.; Peteira, B.; Kerry, B.R. A molecular diagnostic method for detecting Nacobbus in soil and in potato tubers. Nematology 2005, 7, 193-202. [CrossRef]

47. Ophel-Keller, K.; Mckay, A.; Hartley, D.; Herdina; Curran, J. Development of a routine DNA-based testing service for soilborne diseases in Australia. Australas. Plant. Path. 2008, 37, 243-253. [CrossRef] 